終りに御指導睗わつた京都大学教授桜田一郎博士，さ らに発表を許可された会社当局に謝意を表します。

\section{文献}

1) 熛葉; 繊学誌, 15, 354 (1959)

2) E.H. Müller ; Kolloid-Z., 115, 118 (1949)

3) E.H. Müller ; Kolloid-Z., 126, 65 (1952)

4) 吉岡; 緎学誌, 13, 722 (1957)

5) 井本; 緎学誌, 13, 808 (1957)
6) 生駒 ;

7) 島内；高分子，8，202 (1959)

8) Greisenthwaite ; Chem. Int., p. 719 (1958)

9) Greisenthwaite; Chem. Ind., p. 1114 (1958)

10）朝比奈, 田畑; 高分化, 17, 325 (1960) 朝比奈，小林，佐藤；高分子討論会 (1959)

11）渡辺, 堀田; 工化, 61, 1322 (1958)

12) G. Natta ; J. Poly. Sci., 16, 143 (1955)

13) 吉岡 ; 緎学誌, 11, 239 (1955)

\title{
低温重合ポリ塩化ビニルの延伸（その 2）（特に延伸初期過程について）
}

\section{1. 緒言}

前報1)に拈いてわれわれは低温重合 PVC の延伸過程 を密度およびX線的に追求し，その過程に拈ける結晶 化, 結晶の大きさの変選などの様子を明らかにし, 熱収 樎率と延伸率の関係についても考察したが，これらの観 察はすべて延伸率の比較的高い領域に限られ，延伸初期 の過程について特に注目することはしなかつた。しかし 低温重合 PVC 繊維の特に延伸率の低いものは, 普通 PVC の場合に比して種々特異な興味ある性質を示す。 本報では特に延伸初期の過程に注目し, 低温重合 PVC の延伸機構に考察を加えたい。

\section{2. 実験について}

a. 試 料

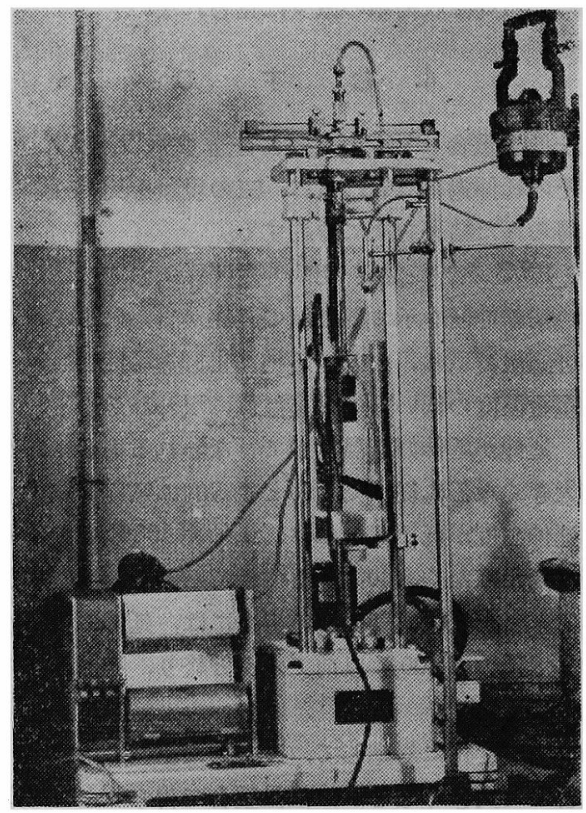

Fig.1. Tensile tester, used in the experiment
この実験には主として第 1 表に示す如き重合温度の異 なる 2 種の PVCを用いた。これらの重合物はいずれむ 第 1 報に記した方法に従つて湿式で紡系し，ほほ $500 \mathrm{~d}$ の充分に乾燥した無配向の繊維状試料とし, 次の実験に 供した。

\section{b. 張カ-温度の関係}

第 1 図の引張り試験機を用い一第 1 表 実験に供 て, 張力の温度依存性を調べ た。具体的には $130^{\circ} \mathrm{C}$ のグリセ リン浴中で, 試料に所定の伸び を与え, 充分平衡達してから の張力を読み, 後温度を $5^{\circ} \mathrm{C}$ す゚

\begin{tabular}{|c|c|c|}
\hline 試料名 & $\begin{array}{|ll|}\text { 重 } & \text { 合 } \\
\text { 温 } & \text { 度 } \\
\end{array}$ & 重合度 \\
\hline S-3 & $50^{\circ} \mathrm{C}$ & 1,300 \\
\hline F-5 & $-15 \prime \prime$ & 1,250 \\
\hline
\end{tabular}
つ下げて各温度における張力の平衡値を読んだ。温度は $130 \sim 50^{\circ} \mathrm{C}$ の範囲で行なつたが, 各温度で張力の平衡値 を得るには 10〜30 分を要した。このような高温におけ る張力は極めて小さく，単䒺での測定は困難であつたの で, 10〜15 本の緘維を平行に並べてクランプし，その張 力を测定した。またこの場合はグリセリン浴中での張力 を測定することになるので，クランプの浮力を無視でき ない。その故に各温度でクランプの孚力を実測し, 補正 曲線を作つて，各温度の測定値を補正した。

\section{c. 密 度}

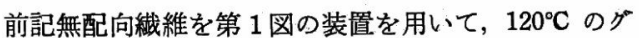
リ七リン浴中で所定倍率に延伸し，その温度で充分張力 の平衡に達せしめたものを急冷固定し, 室温に放置した 後, $30^{\circ} \mathrm{C}$ の密度を測定した。密度の測定は四塩化炭素ノルマルヘプタン系の密度勾配管法によつた。

\section{3. 実験結果および考察}

\section{a. 張力の温度依存性}

S-3 招よび F-5 試料の各伸張率に和ける張力-温度関 係を第 2 3 図に示した。いま張力を $f$ とし, 長さを $l$ とすると, 張力を受けて平衡状態にある物体について は, 次の熱力学的状態式が成立する 2,3$)$ 。故にこれらの図 に特ける直線の横軸とな市を $\theta$ とする 


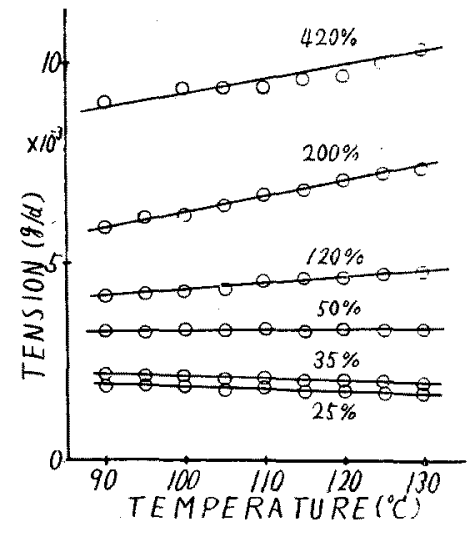

Fig. 2. Tension-temperature relationships, S-3

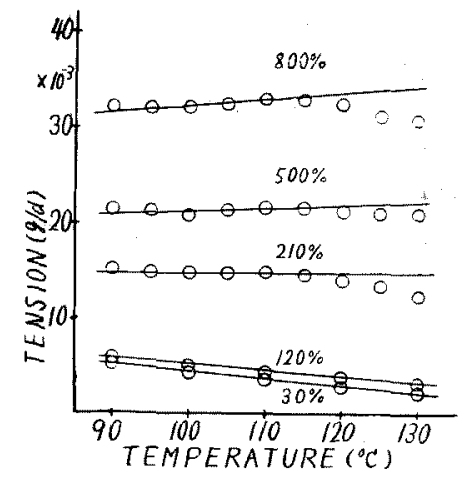

Fig.3. Tension-temperature relationships, $\mathrm{F}-5$

$$
\begin{gathered}
f=f_{E}+f_{S}, \quad f=(\partial E / \partial l)_{T}-T(\partial S / \partial l)_{T} \\
E \text { 一内部エネルギー } \\
S \text { 一エントロピー } \\
T \text { 一絶対温度 } \\
f_{E} \text { 一張力のエネルギー成分 } \\
f_{S} \text { 一張力のエントロピー成分 }
\end{gathered}
$$

と，正線の勾配 $\tan \theta$ は次式で示される。 $\tan \theta=(\partial f / \partial T)_{L}=(\partial S / \partial l)_{T}$

また直線の維軸との交点の座標を、とすると， $a=(\partial E$ $|\partial b\rangle_{T}$ である。このような関俰は熱力学的な可逆過程に 和いてのみ成立することはすちろんであり，測定中に結 晶化度が变和るだの不可逆過程についての取り报いは 複雑になる。

S-3 については第 2 図の如く，420\% 伸張のものを除 いて，乙の張力一温度関係は，因中の温度範国で直線と なり，その勾配は温度と無関係に一定である。知可逆 性す良好で㐫つた。

しかし F-5 については第3図に見られる如く，特に $200 \%$ 以上の伸張率において，㕕い温度域に少たる直線 関俰は得られず， $115^{\circ} \mathrm{C}$ 以上の張力は一般に低い㯰を示
す。こ礼はこの巽常性を示す温度域が, 結晶化好適温度 域)と一致することから考劣てて, 結晶化による容積变化 に起因するものと考光られる。またガラス転移温度付近 になると，平衡達する案での時間の影響もあつて，張 力は一般に高い値を示す。この中間の温度域に持ける張 力温度関係は泀淔線となるが，その涺度域は非常にせ まく，可逆性を充分汇磪かめることはできながつた。

これらの直楾は図に見られる如く，低い伸長率に拉い ては負の匂配を持ち，伸張率が高くなるにつれて正の勾 配を持つようになる。

第 2 3 表には，第 $2 \sim 3$ 図加ら算出した張力のエン トロピ一成分 $f_{S}$ ，およびエネルギ一成分 $f_{E}$ をまる た。またこれらの表の值から伸張率と彋力, 括よび艺の 各成分との関保点点緅し第 4〜5 図に示した。

一般に高分子物質のゴム状弹性を示す温度域にむいて は，伸長によつてェントロピーは減少し，内部エネルギ 一も減少する。そのために張力のエントロピ一成分 $f_{S}$ 正の值をとり，伸張率の增加に従つてその值は大さくな

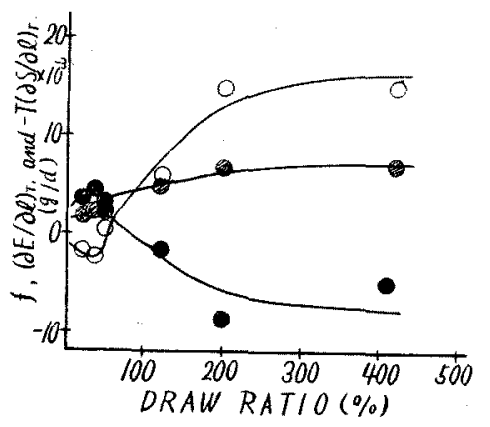

Fig. 4. Change of tension, and its two components with draw ratio. S-3

$O$ entropy component

- energy component

0 tension

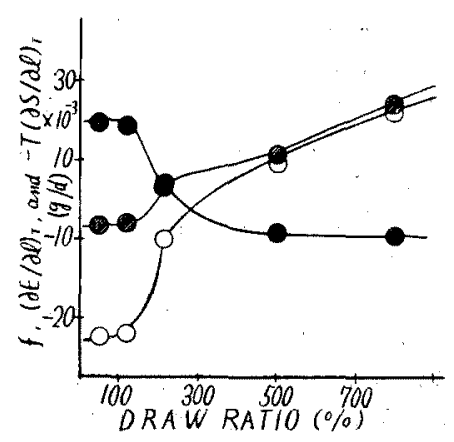

Fig. 5. Change of tension, and its two components with draw ratio. F-5

$O$ entropy component,

- energy component

tension 
第 2 表 F-5 の張力，括よびその各成分

\begin{tabular}{|c|c|c|c|c|c|c|}
\hline 伸張华 $(\%)$ & \multicolumn{2}{|c|}{$f(g / d)$} & \multicolumn{2}{|c|}{$\begin{array}{r}(\partial E / \partial l) T \\
(g / d)\end{array}$} & \multicolumn{2}{|c|}{$\begin{array}{r}-T(\partial S / \partial l) T \\
(g / d) \\
\end{array}$} \\
\hline 50 & $3.7>$ & $10^{-3}$ & 28.3 & $10^{-3}$ & -24.6 & $\times 10^{-3}$ \\
\hline 120 & 4.5 & $"$ & 28.5 & $"$ & -24.0 & $\prime \prime$ \\
\hline 210 & 14.7 & " & 14.7 & " & 0 & $"$ \\
\hline 500 & 21.6 & $"$ & 2.5 & $" \prime$ & 19.1 & $\prime \prime$ \\
\hline 800 & 32.8 & $"$ & 1.5 & $" \prime$ & 31.3 & " \\
\hline
\end{tabular}

第3表 S-3 の張力，扰よびその各成分

\begin{tabular}{|c|c|c|c|c|c|c|}
\hline 伸張絮(\%) & \multicolumn{2}{|c|}{$f(g / d)$} & \multicolumn{2}{|c|}{$\left.\right|^{(\partial E / \partial l) T}(g / d)$} & \multicolumn{2}{|c|}{$\begin{array}{r}T(\partial S / \partial I)_{T} \\
(g / d)\end{array}$} \\
\hline 25 & \multicolumn{2}{|c|}{$1.8 \times 10^{-3}$} & \multicolumn{2}{|c|}{$3.8 \times 10^{-9}$} & \multicolumn{2}{|c|}{$-2.0 \times 10^{-8}$} \\
\hline 35 & 2.1 & $" 1$ & 4.5 & $"$ & -2.4 & $"$ \\
\hline 50 & 3.3 & $" \prime$ & 2.6 & " & 0.7 & $"$ \\
\hline 120 & 4.6 & $"$ & -1.7 & " & 6.3 & $"$ \\
\hline 200 & 6.7 & $\prime \prime$ & -8.5 & " & 15.2 & $"$ \\
\hline 400 & 9.6 & $" \prime$ & -4.5 & " & 14.1 & $" \prime$ \\
\hline
\end{tabular}

る。またエネルギー成分 $f_{E}$ 梳の值をとり，伸長率の 增加优従つてその絶対值を增す ${ }^{3,5)}$ 。PVC に捄いてもを

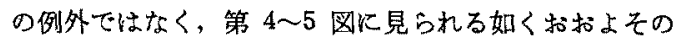
傾向として，伸長によりエントロピーは減少し，内部土 ネルギーる減少するが，伸張の初期に拉いては，逆の傾 向を示し，伸張によりむしろェントロピーが增加し，同 時に内部エネルギーも增加する。

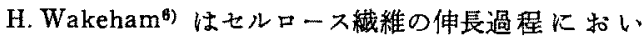
て，同様の事実を認め，伸張の初期比括けるエントロピ 一の減少は，絾維内部に和外る比較的弱い結合が，伸張 汇よつて破溒されるためであると論じている。PVCに ついてのわれわれの結果では，S-3 の場合 50\% 以下の 伸長率の領域では，延伸によりニントロピーが增加し， 内部エネルギーる增加するが，低温重合で得られた F-5 の場合は，この異常領域は更に拡大され，延伸率 200\% 汇いたつて始めてエントロピーの堿少が認められる。更 にこの場合は伸長による各成分の変化が，普通重合の S-3に比して著るしく大きいことも特長である。

また F-5 亿括いては，相当高い伸長率に括いても張 カのエネルギー成分 $f_{E}$ が正の值を示している。これ は, 高率な延伸を行なつてすな执内部エネルギーが增加 する傾向を示すものであり，高率延伸による収縮率の低 下光，扣上び密度の增加などの事実と相反する。後述す る如く，F-5 のガラス転移温度は S-3 のそれより高温 側にあるため，比較的ガラスス化温度に近い温度域の湘定 では充分な平衡值が得られなかつたためと思われる。そ のことを考慮に入れると延伸による張力各成分の変化は 更に大きくなる。

\section{b. 密度变化}

前項では PVC 瀻維の延伸初期過程に扒いて，延伸に よりエントロピーが增加し，また内部エネルギーも增加 する領域があり低温重合物に批いては，この領域が普通
PVCより更汇広い籍囲に执張されることを述べた。こ の事実纴 Wakeham $^{6)}$ の如く，延伸初期に括いて，最初 に存在していた比較的不安定な網目が破壊されると考え ることによつて理解できるが，綱目の破壊は当然密度の 减少を伴なわ权ばならない。第 6〜7 図では延伸初期の 過程に打当延伸率と密度の関係を示した。第 6 图で明 らかな如く，S-3 の場合は延伸初期飞括いて明らか儿密 度が減少し，後急激に增大する。

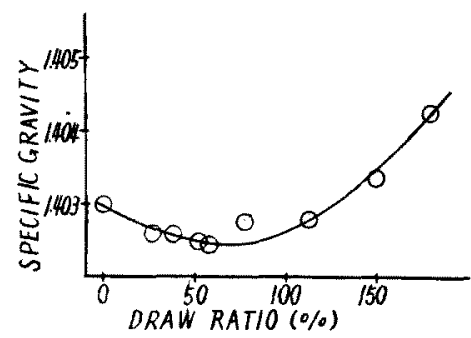

Fig.6. Change of density with draw ratio. S-5

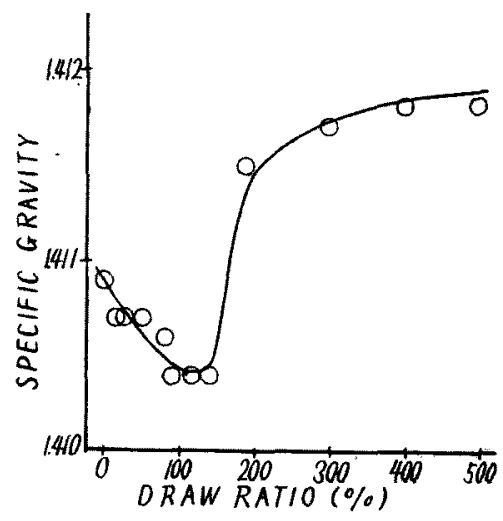

Fig. 7 Change of density with draw ratio. F-5

密度の減少を示すのは延伸率 50\%以下の領域であり， 前項の異常領域々一致する。F-5 の場合恃第 7 四の如く 延伸率 150\% までは密度の减少が著るしい。F-5 につい ても，延伸による密度の减少領域と，エントロピーの增 加する領域が一致することは興味のある事実である。か くの如く PVC 䋐維の延伸に怙いてては，その初期の段階 でェントロピーが增加し，同時に密度の減少を伴なる如 き構造変化の起ることは明らかであり，しかも低温で重 合した PVC の場合には，密度の減少は著るしく，また 普通のPVC に比してより高い延伸率までこの異常領城 が続く。

A.B. Kusov7) は加硫度のそれぞれ異るゴムとついて， その伸長過程における比容の变化を調へ，一般に伸長の 初期に打いて比容が增加し，ある伸長度を過きるを逆比 減少するがこの比容の增加する伸長率の領域は, 加硫度 が高くなる程高い伸長率迄搪張される事実を，伸長の衫 
期段階で綱目の一部が可断されるための比容增加とし、

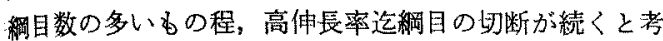
察したが，PVCについての筆者らの結果に叔てむ同 様な考察が可能である。すなわり延伸によつて配向した

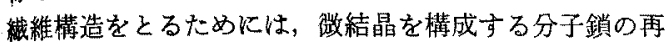
配列が必要と考古られるが，この再配列が行なわれるた るには, 延伸前に存在していた微結晶の破壞, または細 分が行なわれなければならない。

その過程に括いては，密度の減少が見られ，エントロ ピーが增加すると同時に，内部エネルギーの增加するこ とは当然である。

また低温で重合した PVCは結晶性が此較的高く，延 伸によつて再配列するために破瓌さるべき溦結晶の数が 多いたみに，その異常過程は普通のPVC に比してより 高い延伸率迄続くと考光られる。

\section{c. ガラス転移温度}

以上はガラス転移温度以上に括ける張力の湘定結果の みを対象として考察したが，測定した全温度域にわたつ て, 温度張力の関係を点綴すると，第 8９ 9 図に示す如 くなり，低温部と高温部ではそれぞれ別の直線関係に分

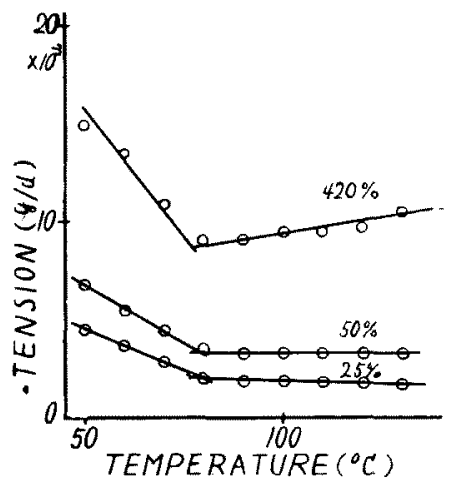

Fig. 8. Tension-temperature relationships. S-3

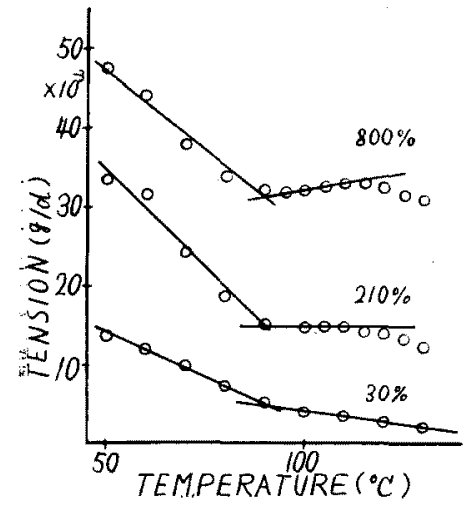

Fig. 9. Tension-temperature relationships. F-5
けられる。それはガラス転移温度より低い温度において は $(\partial E / \partial l) \gg T(\partial S / \partial l)_{T}$ となり，温度と張力の関係は大 きな負の勾配を示すためであるが，この低温部の直線と

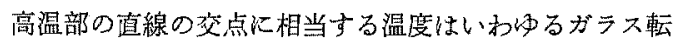
移点とされて出り ${ }^{8)}$, 伸長率と無関係に一定の值を示す のが普通である。2 種の PVC についてのわれわれの实 跧に特いても，この交点から求めたガラス転移温度は， 伸長率を变えても殆九と一定の值を示している。すなわ ち S-3 のガラス転移温度は $75 \sim 80^{\circ} \mathrm{C}$ であり，F-5の

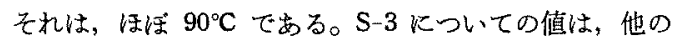
方法による測定結果”)之一致する。第 4 表には董合温度 の異なる 3 種の PVCについて，種々な測定法によつて 得られたガラス化温度ををとめた。

第 4 表 重合温度の異なる PVC のガラス転移温度

\begin{tabular}{|c|c|c|c|}
\hline 重合温度 & $55^{\circ} \mathrm{C}$ & $-15^{\circ} \mathrm{C}$ & $-30^{\circ} \mathrm{C}$ \\
\hline ガラス転移点 & $75 \sim 80^{\circ} \mathrm{C}$ & 㱠 $90^{\circ} \mathrm{C}$ & 略 $95^{\circ} \mathrm{C}$ \\
\hline 測 定 法 & $\begin{array}{l}\text { 誘電率楾膨張 } \\
\text { 張力一温度 }\end{array}$ & 張力一温度 & 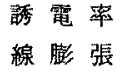 \\
\hline
\end{tabular}

\section{4.むすび}

以上 PVC の張力-温度関係，および延伸率-密度の関 係を調へて，PVC 絾維の延伸初期過程について考察し た。その結果を次に総括する。

PVC の伸長初期の段階では，伸長によつてエント口 ピーが増大し，また内部エネルギー名增加する異常な領 域の存在することがおかつたが，低温で重合した PVC は, 普通のPVCに比して, この領域が広く，また延伸 による張力各成分の变化が大きい。

密度測定の結果は，上述のエントロピー，および内部 エネルギ一変化によく対応し，小加る翼常領域に和い ては延伸によつて密度は明らかに減少し, 後急激に増加 する。

これらの事事から，PVCを延伸する場合には，最初 に存在していた㮶目の一部が破壊され, 別に綱目の再構 成が行なわれて，安定な絾維構造をとることになるが， 低温重合のPVC は普通のものに比し，延伸初期の過程 で破壤さるべき綱目の数が多いと考去た。

終りに御指導晹つた京都大学教授桜田一郎博士，およ び発表を許可された会社当局に謝意を表します。

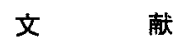

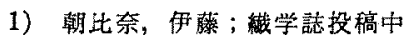

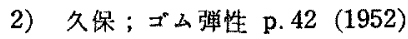

3) 野口; 実験化学諈座 8 , 高分子化学 (下) p. 187 (1957)

4) 朝比奈, 田畑; 高分子化学投稿中

5) J.F. Clark ; J.Text. Inst., 44, 1596 (1953)

6) H. Wakeham; Text. Res.J., 32, 593 (1953)

7) A.B. Kusov ; Kolloid. Zhur., 19, 587 (1957)

8) Robert S.Witte; J.Appl. Phys., 22,689(1951) 


\section{低温重 合 PVCの延伸（その1)}

\section{呉羽华成株式会社 朝比奈光雄・伊藤順夫}

\section{（その 2） 特に延伸初期過程について}

\section{朝比奈光雄・安藤昭夫 \\ DRAW ING OF POLY (VINYL CHLORIDE) POLYMERIZED AT LOW TEMPERATURE (PART 1)}

By Mitsuo Asahina and Yorio Ito

(Kureha Kasei Co. Ltd., Tokyo Laboratory, Hyakunin-cho. Shinjuku-ku., Tokyo, Japan)

\section{DRAWING OF POLY (VINYL CHLORIDE) POLYMERIZED AT LOW TEMPERATURE (PART 2)}

By Mitsuo Asahina and Akio Ando

(Kureha Kasei Co. Ltd., Tokyo Laboratory, Hyakunin-cho, Shinjuku-ku, Tokyo, Japan)

(Part. 1) Fiber were prepared from various kinds of polyvinyl chloride (PVC) polymerized at different temperature under various drawing conditions. The following results were obtained from the measurements of the density, the heat shrinkage and the X-ray difraction in these different kinds of fibers.

1) The observation of the relation between the temperature and the degree of extention at break shows the existence of the temperature range where the degree of extension at break becomes. very high. This optimum temperature range for extension coincides with the heat treating: temperature range which renders the highest density And as the temperature of polymerizaion is lowerd, that optimum temperature range shifts to the higher temperature.

2) Within the optimum temperature range for extention the density increases almost linearly with the degree of extention, but below this almost no density increase was observed up to the degree of extention of $400 \%$ and it begins to increase when the degree of extention exceeds $400 \%$. At the temperature range higher than this optium temperature range the increase of the density is observed mainly before the degree of extention reaches $400 \%$ and the increase of the density over $400 \%$ extention was not remarkable.

3) Corresponding to the variation in the density, the dimension of the crystallite determined from the X-ray study increases with the increased dgree of extention. And the degree of the increase of the dimension of crystallite is higher in the PVC polymerized at low temperature.

(Part 2) The temperature dependence of the two kinds of polyvinyl chloride (PVC), polymerized at different temperature on the tensile strength, was measured at various extention ratios. At the initial stage of extention, an anormalous range was observed where the entropy as well as the internal energy are increased. With PVC polymerized at lower temperature, this range is observed to be wider and the change of each component of the tension caused by drawing is larger as compared with ordinary PVC.

The density measured at each step corresponds well with the entropy and the internal energy change. The density of the sample decreases by drawing it within the anormalous range and then it 
increases abruptly after the anormalous range is surpassed.

Considering the above facts, when PVC is subjected to drawing, the partial break down of the initially existed net work occurs first, and this is succeeded by the recombination and reconstruction of a new net work and thus result into a stable fibre structure. The initially existed net work which has to be broken down at the initial stage of drawing seem to be much dense in PVC sample prepared at lower temperature than in the ordinary PVC.

(Received November 20, 1959)

\section{低温重合 PVC の延伸（その1）}

\section{1. 緒言}

低温重合によつて得られたポリ塩化ビニル（PVC）の

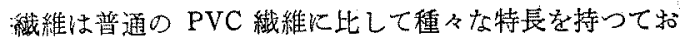
り, 特に加熱收維事の少い点で普通 PVC 緎維に儤越す ることは既行知られている1。

それはもちろん，原料となる低温重合 PVC の持つ本 質的な特性沉起因寸ることはいらまでるない。しかし裁

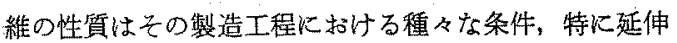
打よび熱処理条件によつて大きく左右され，単純に原料 高分子の性質のみによつて規定されるるのでないことは るち万んで劣る。従来 PVC 緘維の延伸，熱処理などに

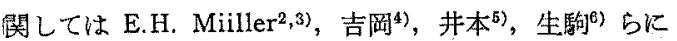
よつて多くの研究が成されて蛙り，その過程に乱ける種 々な現象が観察されている。低温重合 PVC が普通の PVCに比して，分子鎖の規則性がよく ${ }^{729}$, 㓮直な性格

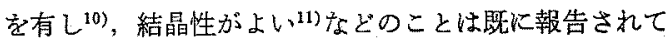
いることであるが，そのような本質的な特異性に起因し て, 低温重合 PVC 緎維の延伸過程において山種々特異 な現象が観察される。本報では重合温度のそれぞれ異な る3 種の PVC とついて, 織維の延伸過程における二, 三の現象老比較観察し，低温重合 PVC の特異性を明ら かにしたいと思う。

\section{2. 実験について}

\section{a) 試 料}

この実験を通じて使用した重 合物第 1 表江示す。これらの 試料はいずれも $7 \%$ (重量)の シクロヘキサノン溶㢈とし第 1 図の装監を用いて，メタノール
第 1 表 実験见使 用した誠料

\begin{tabular}{|c|c|c|}
\hline 試料名 & 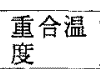 & $\mid \begin{array}{l}\text { 重合度 } \\
\mathrm{Pv}\end{array}$ \\
\hline$S-3$ & $55^{\circ} \mathrm{C}$ & 1,300 \\
\hline $\mathrm{XF}-13$ & $5 \prime \prime$ & 1,250 \\
\hline$X F-4$ & $-30 \prime$ & 1,350 \\
\hline
\end{tabular}

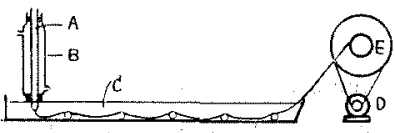

Fig. 1. Spinning apparatus
A : Solution
B : Hot water
C : Coagulation bath
D : Motor
E : Bobbin

: 水=1:1の混合凝固浴中に紡出した。紡系液の温度 扣よび㠜固浴の温度は多くの場合室温としたが，室温で 急速にダルする如き場合には，紡系液貯槽部を温水で加 温することによつてゲル化を助いた。なるい゙無配向の 試料を得るために，浴中で孫が常にたるんでいるよう に注意して港取った。搃取られた糸はボビンから外して 風乾し，大部分の溶剂が蒸発し去つた後，二硫化炭素に 一昼夜以上浸せきして残つた溶剤を置換 し，後减圧下で 定量になるすで乾燥した。

\section{b) 延 伸}

このよ5ルして作つた略 $500 \mathrm{~d}$ の延伸禾は所定温度 のグリセリン浴中で，所定の倍率に延伸した。この場合 の延伸速度はすべて $200 \%$ 秒 としな。また末延伸系の 高温に批りる引張り特性を調べたが，その場合虹加熱装 置を付した引張り試験機を使用し、グリセりン浴中で伸 長し伸長過程の地力-歪関保を抵抗線歪計によつて記録 した。この場合, 試長を $1 \mathrm{~cm}$ にとり, 伸長速度を 40 $\mathrm{cm} /$ 分とした。

\section{c) 密 度}

四塩化炭素一ノルマルヘプタン系の密度勾配管法によ

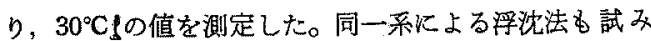
たが，試料間の僅かな差を相詨的に比較するためには， 浮沈法は不適当であつた。

\section{d) $\mathbf{X}$ 線回折}

この実験の場合江延伸による微結晶の織維軸化直角な 方向の大きさの变遷を調べることを目的としたので，赤 道沿つた干涉曲線を求め, パックグラロンドを差引、

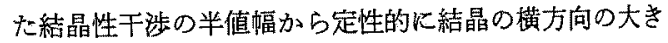

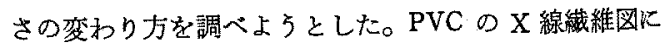
特ける赤道上の干涉としては，Natta ${ }^{12}$ ) の指数配当沉徒 えば，(200+010)，(110)，(210)，(310) 括よび (410+ 220）なとのほぼ 5 個の干涉像がみられるが，これらの 内強度の比較的強いのは $(200+010)$ そ!(110) の二個で ある。この 2 個の干涉像は互儿接近して路，分離して 定量することが極めて困難であつたので，(200+010)+ (110）を便宜上 1 つの干涉と見做し，その半值幅学微結 晶の横方向の大きさを示す定性的な尺度とした。 